\title{
Creating Collaborative Literacy Teams To Increase Reading Achievement In Urban Settings
}

Marlene Zakierski, Iona College, USA

Alice Siegel, College of New Rochelle, USA

\begin{abstract}
The purpose of this article is to provide a detailed example of effective professional development for teachers that resulted in positive changes to the effectiveness of the school's reading program. This study describes the results of an intervention school-wide program that was conducted in a large urban school with a majority of minority students whose families were below the poverty line. With the implementation of continuous professional development of exemplary literacy instruction, dramatic improvement in reading achievement occurred. The article depicts how poorly students performed on state exams and details the multiple strategies developed and used by the authors - analyzing test results, realigning the curriculum, coaching, after school tutoring, and the implementation of a nightly home reading program, all of which were closely monitored by these researchers. This model can be replicated anywhere because it is achievable without any additional cost to the participating schools.
\end{abstract}

Keywords: Professional development, Literacy, Case Study, Urban Schools, Student achievement against all odds, Turnaround schools, Leveling the playing field for students in urban schools, Operating under current budget constraints ability to enhance student achievement, NCLB Act, Teacher development

\section{INTRODUCTION}

\section{How the Impact of Poverty Effects Student Achievement}

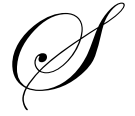

ecretary Arne Duncan in his speech (2009) stated that it is a public school's obligation to teach all students to their full potential. He goes on to state that education is the civil rights issue of our generation. "Children today in our neediest schools are most likely to have the least qualified teachers. And that is why great teaching is about more that education —it is a daily fight for social justice."

The NCLB Act (2001) challenges all public schools to implement tougher standards. Its aim is to close the achievement gap and requires that these standards apply to all students regardless of race, socioeconomic standards, disability and English proficiency (USDepartment of Ed, 2004). This legislative mandate does not decree how schools should achieve success nor the type of reading program or methods -only that the reading instruction must be comprised of research-based practices (Dearman \& Alber, 2005)

Many researchers support the negative impact of poverty on reading achievement. Schools are not prepared to meet the increasing numbers of children of poverty. (Pellino, 2008). The percentage of struggling readers negatively influences every student's reading performance (Kainz, K. \& Vernon-Feagans, L., 2007). There is a link between school performance and students in poverty. It is a clear pattern that students from high socioeconomic status have higher achievement growth (Goodwin, 2000).

Cuban (1992) described two types of school reform efforts: incremental changes, which aim to improve the existing school structures, and fundamental changes, which aim to transform and permanently alter the existing school structures. He purports that neither can be accomplished without adequate professional development. 
These authors strived to change both existing structures and transform them permanently by providing effective professional development for teachers that resulted in positive changes in students' achievement levels. We can report the evidence of the sustained success of our school reform efforts: After two years this school was awarded the IRA NYS Exemplary Reading Award; and after five years it was awarded the National Blue Ribbon.

\section{CASE STUDY}

This case study explains what transpired in a public elementary school in New York State where the authors trained the staff in exemplary instructional practices. This school's population consisted of a majority of minority students who received free and reduced lunch. It was expected that these students would not achieve academically due to their socio economic status.

Prior to the researchers' intervention, only 68 percent of all fourth graders met the learning standards. After one year of intervention strategies, $93 \%$ of the students achieved mastery on the State exam, scoring a 3 or a 4. Remarkably, this success has been maintained over the past five years. Explanation of the assessment rubric is as follows:

Level 4 - Achieved mastery

Level 3 - Met the learning standards

Level 2 - Partially meets the learning standards

Level 1- Shows serious academic problems

The first section of the case study conveys the demographics of the intervention site. The second details the methodology employed by the researchers: The final portion tells the extraordinary results. This school exceeded expectations and proved that by the creation of collaborative literacy teams it is possible to close the achievement gap. This model can be replicated because of the following: it produced a sense of shared experience and feeling part of a team that learns to problem solves together and it produced a paradigm shift in the delivery of reading instruction; and it is surprisingly achievable without any additional cost to a participating school/ school district.

\section{Demographics}

Demographically speaking, Table 1 outlines the school's percentages:

\begin{tabular}{|l|c|}
\hline \multicolumn{2}{|c|}{ Table 1: Demographic Factors } \\
\hline \multicolumn{1}{|c|}{ P.S. \#1 } \\
\hline Percentage of Free or reduced Lunch & $51.0 \%$ \\
\hline Percentage of English Limited & $13.7 \%$ \\
\hline Percentage of African American & $80.2 \%$ \\
\hline Percentage of Hispanic & $13.9 \%$ \\
\hline Percentage of Other & $5.9 \%$ \\
\hline
\end{tabular}

\section{METHODOLOGY}

The first step was to examine the data from the prior year's state exams and based on this analysis, it was determined that many programmatic changes were necessary. The researchers pointed out what skills the students needed in order to be successful on the state exams.

The next step was the expansion of the instructional literacy schedule from a one hour to a 2-hour uninterrupted time block per day. This program included reading, writing listening and speaking.

The proposed intervention required that the program would be skill and strategy based and would include selected pieces of authentic literature. 
Weekly, grade meetings were held to ensure that students had achieved mastery and to inform further instruction. This monitoring of student achievement afforded the teacher the opportunity to assess a child's reading behaviors in a one-on-one setting, and it enabled the teacher to determine a child's reading level that guided instruction for each student. An important element in this program was the training of teachers. Teachers received professional development in analyzing data. Teachers shared data with their team members and problem solved regarding student progress. The information was then charted throughout the school year.

Additionally, teachers were encouraged to expand student vocabulary development. To accomplish this, teachers on all grade levels were required to have daily read-alouds exposing students to the richness of language. Teachers were trained to help students take notes during the read alouds. The students used their notes in book chats, discussion webs and literature circles. This afforded the students the opportunity to share their thoughts and ask critical questions about the literature. Another effective strategy that enhanced reading comprehension was character studies. Literature was selected based upon specific character traits that students could make a text to life or text to text connection.

Another area that teachers received professional development was assessment. Teachers learned how to assess more effectively and efficiently by using a variety of informal assessments such as running records, observation checklists, informal reading inventories.

An integral part of the revised ELA program the researchers also gave professional development to the support staff members consisting of: the reading specialist, art, and media personnel so that they could become effective literacy educators.

The reading specialist addressed individual students who had been identified as in need of academic intervention based on student formative and state assessments. This coach was also seen as a resource to teachers by modeling lessons and taking small groups of students to facilitate learning and develop strategic readers who actively monitored their comprehension.

The media specialist's schedule was adjusted allowing all students to visit the library at least once per week to borrow books during their regular school day. She frequently visited classrooms to conduct book talks where she read aloud a variety of genres, both fiction and non-fiction. Regularly scheduled classes came to the media center to do research. During research class, the media specialist taught and reinforced strategies for reading non-fiction: using the table of contents and index, noting the heading and sub-headings, using pictures and captions.

In the Art classes, students were asked to literally draw common idioms and adages in the "Let's Get Literal" program. A $6^{\text {th }}$ grade acrylic painting project called "Boundaries," based on Robert Frost's "Mending Wall" was another example from the Arts Program that beautifully illustrated the meaningful learning provided by multidisciplinary integration of the curriculum.

This intervention program did not end at dismissal time. In an effort to extend literacy activities, independent reading time and to get parents involved and promote life-long readers, an at-home reading program called Book - In - A Bag was instituted. In this program, students were required to read a book provided by their teacher at home with an adult nightly. Books were sent home with activities that the student and parent could do together. The student and parent kept a daily log of books read that was checked by the classroom teacher. Teachers ensured that Book-in-a-Bag books that were sent home were books that were at that child's independent reading level. For fourth grade a new book was received every two weeks.

Additionally, a late library program was initiated. The 'Late Library' program was part of the school reading program. Students, siblings, parents and teachers were welcome to come to the library after school once a week to read, research and borrow books. The media specialist was present to provide assistance. Also, many parents donated books to celebrate their child's birthday. 


\section{RESULTS}

After only one year of implementation of the intervention program, fourth grade scores rose from $68 \%$ to 93\%. This represents a $33 \%$ increase for the first year. In the second year, $99 \%$ of the students achieved mastery on the state exams and the school received national recognition from the International Reading Association.

\section{SUMMARY}

All this could not have been successfully implemented without a professional development for teachers that focused on improving student learning outcomes by changing teachers' attitudes and beliefs and professional development in exemplary instructional practices. The researchers determined that to increase student achievement in literacy, it is essential that teachers themselves fully understand the process and receive the scaffolding and support they need to guide their students in their learning.

\section{AUTHOR INFORMATION}

Dr. Marlene Zakierski is a professor of Literacy, Teacher Education and Educational Administration at Iona College. She teaches both graduate and undergraduate students.

Dr. Alice Siegel is a professor of Literacy in the graduate program at The College of New Rochelle. The authors have worked together over the last 10 years in various urban school districts in New York State.

\section{REFERENCES}

1. Armstrong, T. (1994). Multiple intelligences in the classroom. Alexandria, VA: Association for Curriculum and Development..

2. Cuban, L. (1993). How Teachers are Taught: Constancy and Change in American Classrooms 1890-1990. New York, NY: Teachers College Press. .

3. Dearman, C. \& Alber, S.(2005). The changing face of education: Teachers cope with challenges through collaboration and reflective study. Reading Teacher, April, 163-4.

4. Ed.gov US Department of Education (October 22, 2009). Teacher Preparation: Reforming the uncertain profession-Remarks of Secretary Arne Duncan at Teachers College, Columbia University, NY.

5. Fountas, I.\& Pinnell, \& G.S. (2001). Guiding readers and writers: Grades 3-5. Portsmouth, NH: Heineman.

6. Goodwin, B. (2000). Raising achievement of low-performing students. Policy brief retrieved from website www.mcrel.org.

7. Kainz, K., \& Vernon-Feagans, L. (2007). The ecology of early reading development for children in poverty. The Elementary School Journal, 107(5).

8. Jacobs, H.H. (1997). Mapping the big picture: Integrating curriculum and assessment K-12. Alexandria, VA: Association for Curriculum and Development.

9. Johnson, D. W., Johnson, R.T., \& Holubec, E. J. (1990). Circles of learning. Edina, MN: Interaction Book Company.

10. Pellino,Karen, (2007). The Effects of Poverty on Teaching and Learning. Teach-nology.com. Retrieved September 30, 2008 hyyp://www.teach-nology.com/tutorials/teaching/poverty/print.htm.

11. United States Department of Education. (2004, February 10). No Child Left Behind Act.

12. Vygotsky, L. S. (1962). Thought and language. Cambridge: MIT Press. 